\title{
Diversifikasi Pangan Asal Ternak Mendukung Keamanan Pangan Nasional
}

\section{(Food Diversification of Origin of Livestock to Support Security National Food)}

\author{
Satriani TA \\ Pusat Penganekaragaman Konsumsi dan Keamanan Pangan, Badan Ketahanan Pangan \\ Kementerian Pertanian, Gedung E Lantai 6, Jl. Harsono RM No. 3, Ragunan, Jakarta Selatan \\ trias27@yahoo.com
}

\begin{abstract}
The main challenge in nation building is to create smart, healthy, qualified and productive Human Resources (SDM). Intelligence and quality of a nation is very correlated with the quality of food consumption and nutrition such as how much consumption of animal protein in a country. Indonesia's animal food consumption at the moment comes mostly from fishery products, but there is a tendency for protein consumption from fish to be reduced, while protein consumption from livestock products is increasing. Until now, the consumption of animal protein from livestock, dominated by egg commodities and chicken meat, for it needs to be encouraged diversification of food from livestock. Activities of food diversification aim to: (1) Encourage the achievement of public demand for various food both fresh and ready to eat; (2) Encouraging the achievement of increased availability of a variety of fresh and processed foodstuffs; and (3) Strengthening and increasing local government participation, mobilizing partners and other resources. The target of the food diversification program is to achieve a variety of consumption patterns, balanced and safe nutrition. Efforts to encourage the diversification of food need to be continued, among others through: (1) Product development through the role of processing industry to improve taste, product image, nutrition and practicality of typical food consumption of the archipelago; (2) National campaign of food diversification based on local food resources to central and local government apparatus, individuals, community groups and companies/industries; (3) Early Systematic food diversification education especially about diverse, nutritious and balanced food patterns; (4) Increasing public awareness not to produce, provide or trade and consume unsafe food; (5) National and regional food pricing programs need to be harmonized, especially in the development of agriculture, fisheries and food processing industries to encourage the production, distribution and consumption of non-rice food sources; and (6) Through the facilitation of the development of fresh food, processed and ready-to-eat food industries based on local resources.
\end{abstract}

Key Words: Food Diversification, Expectation Food Pattern, Energy Sufficiency Rate, Local Resource

\begin{abstract}
ABSTRAK
Tantangan utama dalam pembangunan bangsa adalah menciptakan Sumber Daya Manusia (SDM) yang cerdas, sehat, berkualitas dan produktif. Kecerdasan dan kualitas suatu bangsa sangat berkorelasi dengan kualitas konsumsi pangan dan gizi di antaranya seberapa besar konsumsi protein hewani masyarakat di suatu negara. Konsumsi pangan hewani masyarakat Indonesia pada saat ini sebagian besar berasal dari produk perikanan, tetapi ada kecenderungan konsumsi protein dari ikan semakin berkurang, sementara konsumsi protein yang berasal dari produk peternakan semakin meningkat. Sampai saat ini, konsumsi protein hewani asal ternak, didominasi oleh komoditas telur dan daging ayam ras, untuk itu perlu didorong diversifikasi pangan asal ternak. Kegiatan diversifikasi pangan bertujuan untuk: (1) Mendorong tercapainya permintaan masyarakat terhadap aneka pangan baik segar maupun siap saji; (2) Mendorong tercapainya peningkatan ketersediaan aneka ragam bahan pangan segar dan olahan; dan (3) Penguatan dan peningkatan partisipasi pemerintah daerah, menggerakkan mitra kerja dan sumber daya lainnya. Adapun sasaran
\end{abstract}


dari program diversifikasi pangan adalah agar tercapainya pola konsumsi yang beragam, bergizi seimbang dan aman. Upaya untuk mendorong diversifikasi pangan perlu terus dilakukan, antara lain melalui: (1) Pengembangan produk melalui peran industri pengolahan untuk meningkatkan cita rasa, citra produk, gizi dan kepraktisan konsumsi pangan yang khas nusantara; (2) Kampanye nasional diversifikasi pangan berbasis sumberdaya pangan lokal kepada aparat pemerintahan di tingkat pusat dan daerah, individu, kelompok masyarakat maupun perusahan-perusahaan/industri; (3) Pendidikan diversifikasi pangan secara sistematis sejak dini terutama mengenai pola pangan beragam, bergizi dan berimbang; (4) Peningkatan kesadaran masyarakat untuk tidak memproduksi, menyediakan atau memperdagangkan dan mengkonsumsi pangan yang tidak aman; (5) Program penganekaragaman pangan nasional dan daerah perlu diselaraskan khususnya dalam pengembangan pertanian, perikanan dan industri pengolahan pangan guna mendorong produksi, distribusi dan konsumsi sumber pangan non-beras; dan (6) Melalui fasilitasi pengembangan aneka pangan segar, industri pangan olahan dan pangan siap saji berbasis sumber daya lokal.

Kata Kunci: Diversifikasi Pangan, Pola Pangan Harapan, Angka Kecukupan Energi, Sumber Daya Lokal

\section{PENDAHULUAN}

Tantangan utama dalam pembangunan bangsa adalah menciptakan Sumber Daya Manusia (SDM) yang cerdas, sehat, berkualitas dan produktif. Kecerdasan dan kualitas suatu bangsa sangat berkorelasi dengan kualitas konsumsi pangan khususnya protein. Protein merupakan salah satu zat gizi yang sangat diperlukan oleh manusia dalam pertumbuhan dan perkembangannya. Protein berperan penting dalam pembentukan sel-sel dan jaringan baru tubuh serta memelihara pertumbuhan dan perbaikan jaringan yang rusak. Protein sendiri dibagi menjadi dua kelompok, yaitu protein hewani dan nabati. Sumber protein hewani antara lain daging, ikan, ayam, telur, susu dan olahan lainnya, sementara protein nabati diperoleh dari padi-padian, biji-bijian dan lain sebagainya.

Ketersediaan pangan pada tingkat makro/nasional dipengaruhi oleh produksi dan cadangan. Pada tingkat regional dan lokal ditunjukkan oleh tingkat produksi dan distribusi pangan. Ketersediaan pangan sepanjang waktu dalam jumlah yang cukup dan harga terjangkau sangat menentukan tingkat konsumsi pangan di tingkat rumah tangga. Perencanaan penyediaan dan konsumsi pangan penduduk diharapkan dapat memenuhi tidak hanya kecukupan gizi, akan tetapi sekaligus juga mempertimbangkan keseimbangan gizi yang didukung cita rasa, daya guna, daya terima masyarakat, kuantitas dan kemampuan daya beli. Pemenuhan konsumsi pangan seyogyanya tidak hanya ditekankan pada aspek kuantitas, tetapi yang juga tidak kalah pentingnya kualitas konsumsi pangan atau keanekaragaman konsumsi pangan dengan gizi berimbang. Proporsi energi dari setiap kelompok pangan terhadap total anjuran konsumsi energi memberikan gambaran kualitas atau keragaman dan keseimbangan gizi, yang ditunjukkan dengan skor Pola Pangan Harapan (PPH).

Berdasarkan hasil Susenas yang diolah oleh Badan Ketahanan Pangan (BKP 2017), perkembangan rata-rata kualitas konsumsi pangan masyarakat dalam periode 2014-2016 yang ditunjukkan dengan pencapaian skor pola pangan harapan ( $\mathrm{PPH})$ berfluktuasi setiap tahunnya, terjadi peningkatan kualitas konsumsi pangan yaitu dari 83,4 pada tahun 2014, 85,2 pada tahun 2015 menjadi 86,0 pada tahun 2016 (Angka Kecukupan Energi/AKE $2.000 \mathrm{kkal} / \mathrm{kapita} / \mathrm{hari}$ ). Konsumsi pangan hewani yang menjadi sumber protein hewani juga mengalami peningkatan, namun belum mencapai konsumsi anjuran. Angka kecukupan protein untuk ketersediaan $63 \mathrm{~g} / \mathrm{kapita} / \mathrm{hari}$ dan konsumsi $52 \mathrm{~g} / \mathrm{kapita} / \mathrm{hari}$. 
Komoditas penyedia sumber protein hewani dapat berasal dari ikan dan ternak. Sumber protein hewani asal ternak dapat berasal dari produk daging, telur dan susu dengan kandungan gizi yang berbeda-beda dan sangat potensial untuk ditingkatkan ketersediaannya melalui pengembangan komoditas sapi potong, sapi perah, kambing, domba, kerbau, unggas dan babi. Agar keunggulan protein hewani dapat digunakan dengan baik, perlu dilakukan good practices, dari tingkat budidaya ternak, penanganan pascapanen hasil ternak, pengolahan hasil ternak, distribusi hasil ternak maupun peredaran hasil ternak.

\section{POKOK BAHASAN}

Undang-Undang No. 18 Tahun 2012 tentang Pangan mengamanatkan pemerintah dan pemerintah daerah berkewajiban mewujudkan penganekaragaman konsumsi pangan untuk memenuhi kebutuhan gizi masyarakat dan mendukung hidup sehat, aktif dan produktif. Penganekaragaman konsumsi pangan diarahkan untuk meningkatkan kesadaran masyarakat dan membudayakan pola konsumsi pangan yang beragam, bergizi seimbang dan aman sesuai potensi dan kearifan lokal. Tercapainya penganekaragaman konsumsi pangan sebagaimana diamanatkan dalam UU Pangan, diukur melalui pencapaian nilai komposisi pola pangan dan gizi seimbang dengan menggunakan pendekatan $\mathrm{PPH}$.

Berdasarkan hasil Susenas, capaian skor PPH pada tahun 2016 adalah 86,0, mengalami peningkatan 0,8 dari capaian skor PPH pada tahun 2015. Kondisi ini mencerminkan bahwa penganekaragaman konsumsi pangan penduduk belum mencapai kondisi ideal. Tabel 1 menunjukkan kecukupan energi sembilan kelompok bahan pangan ditingkat ketersediaan dan konsumsi. Konsumsi energi penduduk Indonesia pada tahun 2015 dan 2016 sudah melebihi konsumsi energi anjuran sebesar 2.000 kkal/kapita/hari, namun masih didominasi oleh kelompok pangan padi-padian. Konsumsi kelompok pangan umbi-umbian, pangan hewani, buah/biji berminyak, kacang-kacangan dan sayur serta buah perlu ditingkatkan untuk mencapai konsumsi anjuran.

Tabel 1. Angka kecukupan energi tingkat ketersediaan dan konsumsi (kkal/kapita/hari)

\begin{tabular}{lrrrrr}
\hline \multirow{2}{*}{ Sumber } & \multicolumn{4}{c}{ Ketersediaan } & \multirow{2}{*}{ Konsumsi } \\
\cline { 2 - 4 } & \multicolumn{1}{c}{2015} & \multicolumn{1}{c}{2016} & 2015 & 2016 & AKE ideal \\
\hline Padi-padian & $2.361,9$ & $2.257,9$ & 1.253 & 1.274 & 1.000 \\
Umbi-umbian & 267,5 & 234,7 & 48 & 49 & 120 \\
Pangan hewani & 164,6 & 150,0 & 201 & 211 & 240 \\
Minyak dan lemak & 311,4 & 813,6 & 257 & 265 & 200 \\
Buah/biji berminyak & 76,1 & 74,7 & 44 & 42 & 60 \\
Kacang-kacangan & 154,7 & 80,9 & 57 & 60 & 100 \\
Gula & 249,9 & 157,6 & 102 & 111 & 100 \\
Sayur dan buah & 249,2 & 253,7 & 99 & 96 & 120 \\
Lain-lain & - & - & 38 & 37 & 60 \\
\hline Jumlah & $3.835,3$ & $4.023,1$ & 2.099 & 2.147 & 2.000 \\
\hline
\end{tabular}

AKE: Angka kecukupan energi

Sumber: BKP (2017) 
Data Susenas menunjukkan tingkat konsumsi protein pada tahun 2016 mencapai 60,25 $\mathrm{g} /$ kapita/hari sudah melebihi angka kecukupan protein $52 \mathrm{~g} / \mathrm{kapita} / \mathrm{hari}$ (angka ideal hasil WNPG (2004)). Kontribusi konsumsi protein masih didominasi oleh protein nabati sebesar $40,95 \mathrm{~g} / \mathrm{kapita} / \mathrm{hari}(67,96 \%)$, sedangkan kontribusi protein hewani sebesar 19.30 g/kapita/hari (32,04\%). Namun, pada Tabel 2 menunjukkan bahwa konsumsi protein asal pangan hewani cenderung meningkat tiap tahunnya. Konsumsi protein yang cenderung turun adalah ikan dan telur, untuk ikan pada tahun tahun 2015 sebesar 9,62 g/kapita/hari dan tahun 2016 sebesar 9,56 g/kapita/hari turun 0,06 g/kapita/hari.

Tabel 2. Perkembangan konsumsi protein asal pangan hewani (g/kapita/hari)

\begin{tabular}{lrrrr}
\hline \multirow{2}{*}{ Kelompok pangan hewani } & \multicolumn{4}{c}{ Tahun } \\
\cline { 2 - 5 } & 2013 & 2014 & 2015 & 2016 \\
\hline Ruminansia & 1,26 & 1,33 & 1,48 & 1,75 \\
Unggas & 2,81 & 3,08 & 3,77 & 4,24 \\
Telur & 2,19 & 2,24 & 2,13 & 2,18 \\
Susu & 1,23 & 1,28 & 1,50 & 1,57 \\
Ikan & 9,29 & 9,68 & 9,62 & 9,56 \\
\hline Total & 16,79 & 17,61 & 18,50 & 19,30 \\
\hline
\end{tabular}

Sumber: BKP (2017)

Konsumsi pangan hewani sebagai sumber protein hewani berdasarkan Tabel 1, meningkat dari tahun 2015 ke tahun 2016 namun belum mencapai konsumsi energi acuan sebesar $240 \mathrm{kkal} / \mathrm{kapita} / \mathrm{hari}$. Tabel 3 menunjukkan perkembangan konsumsi kalori yang berasal dari pangan hewani, yang cenderung meningkat setiap tahunnya. Peningkatan konsumsi kalori disumbang oleh konsumsi daging ruminansia, daging unggas dan susu. Namun demikian, konsumsi unggas, telur, susu dan ikan masih belum mencapai konsumsi ideal.

Tabel 3. Perkembangan konsumsi energi pangan hewani (kkal/kapita/hari)

\begin{tabular}{|c|c|c|c|c|c|}
\hline \multirow{2}{*}{ Kelompok pangan hewani } & \multicolumn{4}{|c|}{ Tahun } & \multirow{2}{*}{ Konsumsi ideal } \\
\hline & 2013 & 2014 & 2015 & 2016 & \\
\hline Ruminansia & 14 & 14 & 18 & 20 & 14,5 \\
\hline Unggas & 42 & 46 & 56 & 61 & 77,9 \\
\hline Telur & 28 & 28 & 27 & 27 & 31,1 \\
\hline Susu & 32 & 33 & 39 & 41 & 46,8 \\
\hline Ikan & 59 & 62 & 62 & 61 & 69,8 \\
\hline Total & 174 & 183 & 201 & 211 & 240,0 \\
\hline
\end{tabular}

Sumber: BKP (2017)

Untuk meningkatkan konsumsi protein hewani, maka perlu ditingkatkan pula konsumsi pangan hewani. Konsumsi pangan hewani masyarakat Indonesia sebagian besar berasal dari produk perikanan, tetapi ada kecenderungan saat ini konsumsi protein dari ikan semakin berkurang, sementara konsumsi protein yang berasal dari produk peternakan semakin meningkat. 
Berdasarkan hasil Susenas, partisipasi konsumsi pangan hewani yang tinggi terdapat pada komoditas telur dan daging ayam ras. Berdasarkan Tabel 3, konsumsi energi dari sumber protein yang berasal dari ruminansia sudah berlebih, sementara untuk konsumsi energi dari unggas dan telur masih belum cukup, oleh karena itu perlu dilakukan diversifikasi konsumsi pangan asal ternak.

Badan Ketahanan Pangan terus melakukan upaya untuk mendorong diversifikasi pangan antara lain melalui: (1) Pengembangan produk melalui peran industri pengolahan untuk meningkatkan cita rasa, citra produk, gizi dan kepraktisan konsumsi pangan yang khas nusantara; (2) Kampanye nasional diversifikasi pangan berbasis sumberdaya pangan lokal kepada aparat pemerintahan di tingkat pusat dan daerah, individu, kelompok masyarakat maupun perusahan-perusahaan/industri; (3) Pendidikan diversifikasi pangan secara sistematis sejak dini terutama mengenai pola pangan beragam, bergizi dan berimbang; (4) Peningkatan kesadaran masyarakat untuk tidak memproduksi, menyediakan atau memperdagangkan, dan mengkonsumsi pangan yang tidak aman; (5) Kegiatan penganekargaman pangan nasional dan daerah perlu diselaraskan khususnya dalam pengembangan pertanian, perikanan dan industri pengolahan pangan guna mendorong produksi, distribusi dan konsumsi; dan (6) Melalui fasilitasi pengembangan aneka pangan segar, industri pangan olahan dan pangan siap saji berbasis sumber daya lokal.

Kegiatan-kegiatan tersebut diatas dapat diimplementasikan pada peningkatan diversifikasi pangan yang berasal dari hewan ternak. Hal yang tidak kalah pentingnya adalah peningkatan jaminan keamanan pangan untuk produk pangan asal hewan. Terdapat beberapa kriteria keamanan pangan khususnya asal hewan. Kriteria tersebut antara lain: (1) Keamanan dari aspek mikroba pathogen; (2) Keamanan dari aspek cemaran bahan kimia berbahaya; dan (3) Keamanan dari aspek residu hormon dan antibiotic; dan (4) Keamanan dari aspek bahaya fisik.

Agar pangan segar asal hewan dapat memenuhi standar keamanan pangan, perlu diterapkan tata cara yang sesuai dengan persyaratan good practices, yang mencakup good farming practices, good hiegenic practices, good manufacturing practices, good distribution practices dan good retail practices. Untuk menerapkan good practices di tingkat pelaku, perlu dilakukan sosialisasi penerapan good practices secara berkelanjutan.

Untuk itu dibutuhkan dukungan lintas sektor seperti:

1. Dukungan sektor pertanian untuk mendorong produksi pangan dan pertanian antara lain: (1) Pengembangan teknologi secara terus menerus; (2) pengendalian dan pencegahan pemotongan sapi potong betina produktif; dan (3) Pengembangan pangan sumber protein hewani lainnya.

2. Dukungan sektor perdagangan berupa: (1) kebijakan perdagangan dalam bentuk tarif bea masuk (TBM), sebagai salah satu bentuk perlindungan kuantitatif bagi pertanian di Indonesia; (2) Kebijakan penyederhanaan prosedur ekspor-impor; (3) Pengendalian efektifitas pemberlakuan regulasi pemasukan ternak dan produknya; dan (4) Penyebaran informasi perkembangan harga-harga komoditas penjaminan efisiensi distribusi pangan dan sarana produksi.

3. Dukungan sektor demografi berupa perlambatan laju pertumbuhan penduduk melalui penggalakan kembali program KB untuk memperlambat kenaikan konsumsi.

4. Dukungan sektor perekonomian berupa: (1) Dukungan kebijakan ekonomi makro yaitu fiskal, moneter seperti subsidi komoditas pangan non-beras; dan (2) Investasi dan kebijakan alokasi untuk diversifikasi pangan.

5. Dukungan Kementerian Dalam Negeri berupa: (1) Dukungan kebijakan pengawasan perda; dan (2) Integrasi kegiatan diversifikasi pangan melalui kegiatan pemberdayaan masyarakat. 
6. Dukungan sektor perhubungan berupa ketersediaan kapasitas tarif dan kelancaran arus transportasi, perdagangan serta sarana produksi.

7. Dukungan sektor kehutanan berupa: (1) konservasi hutan lindung dan DAS; dan (2) Rehabilitasi lahan pertanian terlantar yang belum digunakan.

8. Dukungan sektor kesehatan berupa dukungan kebijakan untuk memasyarakatkan PPH melalui gerakan sadar gizi yang mendukung konsumsi diversifikasi pangan.

9. Dukungan sektor komunikasi dan informatika berupa: (1) Dukungan pemasyarakatan program diversifikasi pangan melalui media; (2) Meningkatkan daya jangkau melalui infrastuktur pos, komunikasi dan informatika; dan (3) Mendorong peranan media masa dalam rangka meningkatkan diversifikasi pangan.

10. Dukungan sektor perbankan berupa pemberian modal usaha melalui kredit atau pinjaman lunak dengan bunga rendah.

11. Dukungan sektor koperasi dan usaha mikro, kecil dan menengah berupa dukungan kebijakan untuk penataan dan pengembangan kelembagaan usaha bidang peternakan.

\section{KESIMPULAN}

Kesimpulan dari diversifikasi pangan asal ternak mendukung keamanan pangan nasional adalah:

1. Skor PPH konsumsi terus mengalami peningkatan, tahun 2015 sebesar 85,2 dan tahun 2016 sebesar 86,0 tetapi masih belum beragam.

2. Angka kecukupan energi konsumsi sudah terpenuhi yaitu di atas $2.000 \mathrm{kkal} / \mathrm{kapita} / \mathrm{hari}$, dari tahun 2015 sebesar $2.099 \mathrm{kkal} / \mathrm{kapita} / \mathrm{hari}$ dan tahun 2016 sebesar 2.147 kkal/kapita/hari. Beberapa kelompok pangan yang masih belum tercukupi AKE nya adalah umbi-umbian, pangan hewani, buah/biji berminyak, kacang-kacangan, sayur, buah dan lain-lain.

3. Konsumsi energi pangan hewani menunjukkan peningkatan setiap tahunnya, untuk konsumsi daging ruminansia sudah cukup ideal yaitu $20 \mathrm{kkal} / \mathrm{kapita} / \mathrm{hari}$ dari anjuran $14,5 \mathrm{kkal} / \mathrm{kapita} / \mathrm{hari}$. Sedangkan daging unggas, telur, susu dan ikan masih di bawah AKE.

4. Konsumsi protein pangan hewani mengalami peningkatan dari tahun 2013-2016. Pangan hewani jenis ikan mengalami sedikit penurunan yaitu $0,06 \mathrm{~g} / \mathrm{kapita} / \mathrm{hari}$.

Untuk mensukseskan diversifikasi pangan asal ternak beberapa langkah yang harus dilakukan adalah dengan dukungan oleh semua sektor yaitu sektor pertanian, perdagangan, perekonomian, pemasaran, perhubungan dan sektor lainnya.

\section{DAFTAR PUSTAKA}

BKP. 2017. Badan Ketahanan Pangan. Jakarta (Indonesia): Direktori Pengembangan Konsumsi Pangan, Badan Ketahanan Pangan, Kementerian Pertanian.

BKP. 2016. Rencana strategis 2015-2019 revisi II. Jakarta (Indonesia): Badan Ketahanan Pangan, Kementerian Pertanian.

Dijen PKH. 2016. Grand desain pemenuhan protein hewani asal ternak tahun 2045. Jakarta (Indonesia): Direktorat Jenderal Peternakan dan Kesehatan Hewan, Kementerian Pertanian. 


\section{DISKUSI}

\section{Pertanyaan}

1. Bagaimana untuk menentukan KRPL?

2. Dari data yang disampaikan ada beberapa potensi yang belum dimunculkan, misalnya babi (pada presentasi hanya ditampilkan ayam dan kelinci).

3. Selain itu, di Indonesia Timur mereka berburu dan memanfaatkan hewan liar untuk memenuhi kebutuhan protein hewani, juga belum disampaikan.

4. Saran: Diharapkan nanti ada kajian untuk membuat zonasi ketahanan pangan sehingga dapat memperkaya data secara nasional.

\section{Jawaban}

1. Dari tahun 2010 KRPL mulai dijalankan hingga 2017 disediakan dana 15 juta per kelompok baik untuk kelompok yang sudah eksis maupun untuk kelompok yang baru. Masih banyak yang perlu diperbaiki sehubungan dengan kegiatan ini. Kelemahannya adalah lokasi desa dari kelompok penerima dana masing-masing berjauhan sehingga dampak secara umum belum terlihat, tetapi dampak terhadap masyarakat dalam dan sekitar kelompok sudah mulai terlihat. Dana tersebut biasanya diserahkan kepada pemerintah propinsi untuk menunjuk kelompok yang akan menerima dana. Sistem akan terus diperbaiki dan target untuk tahun 2018 adalah 300 kelompok yang tersebar di seluruh Indonesia. Diharapkan nantinya kelompok-kelompok tersebut akan membentuk suatu kawasan sehingga dampak program tersebut lebih terasa. Saat ini tidak hanya kelompok-kelompok wanita seperti PKK dan darmawanita tetapi juga menyasar untuk kelompok PERSIT dan KOREM. Untuk PERSIT dan KOREM biasanya lebih berhasil karena mereka cenderung lebih mentaati perintah. Karena dana yang diberikan sangat kecil yaitu 15 juta per kelompok maka hanya untuk penumbuhan saja. Bila tidak ada komitmen kelompok maka sistem yang sudah dijalankan lama kelamaan dapat menghilang. Untuk pemenuhan gizi masayarakat diharapkan dapat terpenuhi secara swadaya di sekitar rumah sehingga program ini lebih mengejar jumlah penerima meskipun dana yang dibagikan relatif kecil.

2. Kami belum memasukkan ternak babi karena memerlukan lahan yang lebih luas dibandingkan dengan ayam dan kelinci, selain itu dana yang disebarkan sangat terbatas.

3. Kami tidak menutup kemungkinan sumber protein apapun, disesuaikan dengan potensi wilayah agar lebih baik. Budaya masyarakat akan menjadi penentu diversifikasi pangan dan penentu harga. Hal tersebut yang menyebabkan harga daging sapi per gram paling mahal dibawahnya ada daging ayam dan telur ayam ras.

4. Terimakasih untuk saran yang disampaikan. 